\title{
The Effect of Marketing Mix (Product, Price, Place and Process) on Students' Desire to Recommend Lectures in Tourism Academy of NHI Bandung
}

\author{
Amalia Juliana Monika Intan \\ Akademi Pariwisata NHI Bandung, Indonesia \\ amalia@akparnhi.ac.id
}

\begin{abstract}
The purpose of this study was to determine whether the product, price, place and process partially or simultaneously influence the desirability of students to recommend lectures at the NHI Bandung Tourism Academy. The population and sample in this study were students of the Bandung Tourism Academy. The variables of this research are the variable product (product), price (price), place (place), and process (process) as well as the desire to recommend college. The research method uses an explanatory survey. The data analysis method used is multiple linear regression analysis and using the $t$ test and $F$ test. Research results. Based on the results of multiple linear regression analysis
\end{abstract}

Keywords

product, price, place, process, desire to recommend, AKARNH

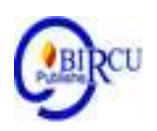

\section{Introduction}

Currently the tourism industry sector in Indonesia is growing rapidly and has become a core business for Indonesia as well as a contributor to Gross Domestic Product (GDP), foreign exchange and a provider of easy, large and fast jobs. The tourism sector's contribution is currently $4 \%$ of the total Indonesian economy.

Based on data from Travel \& Tourism Competitiveness Reportfrom the World Economic Forum, Indonesia's ranking jumped from 70th in 2013 to 50th in 2015, due to the increasing number of foreign tourist visits to Indonesia. What attracts foreign tourists to Indonesia is the presence of a number of cultural heritages, rich natural resources and competitive prices.

Along with the growth of the tourism industry which continues to increase, Indonesia needs to diversify the tourist destinations it offers, so that later it will not completely depend on the attractiveness of the island of Bali and can distribute the benefits of tourism more evenly to all corners of the country. One of the things that need to be improved is by fixing the infrastructure that is not feasible and also increasing the competence of the human resources of its citizens, especially in remote areas, which are less competitive than Singapore, Malaysia and Thailand.

Education is a conscious effort made by adults for human maturity which is carried out in the process of teaching and learning activities, both formally and informally. Education is expected to be able to answer all the challenges of the times and be able to foster national generations, so that people become reliable and of high quality, with strong characteristics, clear identities and able to deal with current and future problems. (Azhar, 2018)

Education is the only way that must be taken to overcome the constraints of a lack of competency in human resources. The participation of tourism education and training, it is necessary to develop both the facilities and infrastructure to improve the quality of tourism services and administration. 
The implementation of tourism education in West Java which is one of the tourist destinations in Indonesia is quite developed, according to the records of LLDIKTI Region IV West Java, showing the development of higher education institutions that specifically open the tourism sector as follows:

Table 1. Higher Education Institutions in the Tourism Sector in West Java

\begin{tabular}{|c|l|}
\hline No. & \multicolumn{1}{|c|}{ Name of Colleges } \\
\hline 1 & Akademi Pariwisata Bandung \\
\hline 2 & Akademi Pariwisata Yasmi \\
\hline 3 & Akademi Pariwisata Siliwangi \\
\hline 4 & Akademi Pariwisata Sandhy Putra \\
\hline 5 & Akademi Pariwisata Nasional Indonesia Bandung \\
\hline 6 & Akademi Pariwisata Citra Buana Indonesia \\
\hline 7 & Akademi Pariwisata NHI Bandung \\
\hline 8 & Akademi Pariwisata Nusantara Tangerang \\
\hline 9 & Akademi Pariwisata (AKPAR) Bina Sarana Informatika Bandung \\
\hline 10 & Universitas Telkom (Program studi perhotelan) \\
\hline 11 & Sekolah Tinggi Ilmu Ekonomi Pariwisata YAPARI \\
\hline 12 & Sekolah Tinggi Pariwisata Ars Internasional \\
\hline 13 & Sekolah Tinggi Pariwisata Bogor \\
\hline 14 & $\begin{array}{l}\text { Politeknik Pajajaran Insan Cinta Bangsa Bandung (program studi } \\
\text { perhotelan) }\end{array}$ \\
\hline 15 & Universitas 17 Agustus 1945 Cirebon (program studi perhotelan) \\
\hline Source: processed LLDIKTI Region IV West Java
\end{tabular}

Seeing from table 1 above, the province of West Java is a number of education service providers in the tourism sector. The development of tourism education service providers will lead to fairly fierce competition, thus demanding service providers to continuously pay attention to the preferences of existing service users, followed by various strategiesgi to reach its target market through marketing mix activities.

The management of higher education is the same as the management of a service business, where satisfaction stakeholder is a measure of the success of a university in managing its management. This can be seen in one of the tourism universities in the city of Bandung, namely the NHI Tourism Academic Bandung.

AKPAR NHI is one of the higher education institutions that hold vocational education in the tourism sector, especially in the hospitality sector, which is a private university founded by the Kopensi STPB Foundation (Bandung Tourism College / NHI Negeri) based on notarial deed No. 2 April 17, 2001.

Since its establishment until now, the NHI Bandung Tourism Academy has received many students through several strategic policies in the field of marketing, so that they are able to compete with other tourism universities in West Java, this is evident from the data on student admissions that continue to increase as seen in table 2 below: 
Table 2. Number of NHI Tourism Academic Students for 4 Academic Years

\begin{tabular}{|c|c|c|}
\hline No. & Academic year & Number of Students \\
\hline 1 & $2018-2019$ & 802 \\
\hline 2 & $2017-2018$ & 719 \\
\hline 3 & $2016-2017$ & 698 \\
\hline 4 & $2015-2016$ & 472 \\
\hline
\end{tabular}

Source: NHI AKPAR Academic Bureau

Looking at table 2 above, it is clear that the NHI Tourism Academy has increased the number of students from year to yeark for the 2015-2016 academic year to 2018-2019. In addition, based on data from BPS, it shows that the net enrollment rate for Higher Education in 2016 was $23.44 \%$, an increase in 2017 by $25 \%$, and seen from the data aged 19-24 who are still in school, both male and female sex have increased from 2014 to 2017 from $22.74 \%$ in 2014 increased to $22.79 \%$ in 2015 , increased to $23.80 \%$ in 2016 , increased again to $24.67 \%$ in 2017, this means an increase in high school graduates who go on to college.

Even though the data on the increase in high school graduates who continue to university continue to increase every year, unto increase the number of students, educational institutions will not be separated from the service marketing mix strategy. Service marketing mix is organizational elements that can be controlled by the organization in communicating with consumers and will be used to satisfy consumers.

Given the increasingly fierce competition in the world of education, private universities, especially AKPAR NHI, must be able to understand what is the main factor in assessing the quality of service products offered, especially those who are already students at the tertiary institution to get satisfaction with the needs of the educational service marketing mix university which consists of product, price, promotion, people, physical evidence, process.

The marketing mix factor is considered very strategic in influencing consumer behavior in choosing a particular educational institution. The marketing mix factor will be an important instrument for educational institutions in order to continue to increase the number of students. This is in line with some empirical evidence that shows a significant effect of the marketing mix on product consumption decisions or choosing a service.

In reality, consumer behavior does not only involve the decision to consume a product or service, after consuming a product or service (post purchase), consumers will feel satisfaction or dissatisfaction, which then has an impact on the decision to continue or stop using the product / service. Satisfied consumers will produce loyal customers. Consumer loyalty after using service products, one of which is characterized by the act of recommending the product or service to others.

Referring to the phenomenon of the problem above, this research is aimed to see further whether part of the marketing mix (product, price, place, and process) affects the desire of students to recommend higher education to others, because the efforts made by management and students have differences that may not match what the students expect. Based on this and the phenomenon of product, price, place and process problems as well as the desire to recommend lectures at the NHI Bandung Tourism Academy, the authors try to do research with the title "The Effect of Marketing Mix (Product, Price, Place and Process) Against Student Desire to Recommend Lectures at Bandung NHI Tourism Academy". 


\section{Review of Literatures}

\subsection{Definition of Marketing Mix}

According to Kotler and Armstrong (2016: 78) suggesting the marketing mix, one of the main concepts in modern marketing. The marketing mix is a set of tactical marketing tools that companies incorporate to generate the desired response in target markets. The marketing mix consists of everything a company can do to influence demand for its products. Marketing Mix consists of four variables, namely Product, Price, Place and Promotion.

Meanwhile, according to Lupiyoadi (2013: 92) marketing mix is a tool / tool for marketers which consists of various elements of a marketing program that need to be considered so that the implementation of the marketing strategy and the determined positioning can run successfully. The product marketing mix includes the 4Ps, namely product, price, location and promotion. Meanwhile, for service products, these four factors are still deemed inadequate. Marketing experts add three more elements, namely people or human resources (HR), processes and customer service.

According to Tjiptono (2014: 41), the marketing mix is a set of tools that marketers can use to shape the characteristics of the services offered to customers. These tools can be used for long-term strategy as well as for designing short-term tactical programs. The marketing mix is the $4 \mathrm{P}$ (product, price, place, promotion) and then added with the $3 \mathrm{P}$ of services, namely people, physical evidence, and processes.

According to Zeithaml. et al (2006: 25) argues that the concept of the traditional marketing mix consists of 4Ps, namely, product, price, place (distribution) and promotion, while for service marketing (the service marketing mix) there is an element of an expanded marketing mix for services. ) namely people, physical evidence and process, each element of the marketing mix is interconnected and dependent on one another.

According to Alma (2013: 283) there are seven elements of the marketing mix in educational institutions, namely:

1. Products (Products), products in educational institutions can be in the form of product differentiation on the image of the university's name and on the quality of the product itself, including the performance of the university graduates themselves.

2. Price (Price), this element is in line with product quality. If the quality of the product is good, prospective students have the courage to pay higher.

3. Place (Place), a location that is easily reached by public transportation, is sufficient to act as a consideration for prospective students to enter PTS.

4. Promotion (Promotion), elements of excessive promotion have a negative correlation to the attractiveness of enthusiasts. And strong PTS carry out promotions lower than weak PTS.

5. People (People), university leaders, lecturers and staff who will serve are the determining elements in the marketing mix.

6. Physical Evidence, in the form of building displays, laboratories, sports fields, landscaping and so on.

7. Process, how is the process experienced by students while in education, for example the tentamen process, thesis guidance process, the examination process, the graduation process and so on.

According Dianto et al (2020) Marketing is a process of planning and execution, starting from the conception stage, pricing, promotion, to the distribution of goods, ideas and services, to make exchanges that satisfy the individual and his institutions. 


\subsection{Definition of Products}

According to Kotler and Armstrong (2016: 78) defines a product as a combination of goods and services offered by a company to the target market. Keegan and Green (2015: 315) define a product as goods, services, or ideas with tangible and intangible attributes that collectively create value for buyers or users. The real attributes of a product can be assessed from a physical point of view, such as weight, dimensions, or the materials used. Intangible product attributes, including status related to product selection, manufacturer's service commitment, and overall brand reputation, are also important.

The quality of products that are in great demand by consumers can be seen from several factors including packaging, price, quality, and benefits obtained by consumers. With good product quality it will have an impact on consumer loyalty and increase revenue for producers. (Romdony et al, 2019)

Product is a producer subjective understanding of the goods / services offered in an effort to achieve organizational goals (profits) through meeting consumer needs and activities in accordance with consumer purchasing power and organizational capacity.

\subsection{Understanding Price}

Price is a very important part of the buying process and determines the market selection and profit level of the organization. According to Kotler and Armstrong (2016: 78) states: Price is the amount of money customers must to pay to obtain the product, which means that price is the amount of money that customers have to pay to get the product.

The pricing strategy is very significant in providing value to consumers and influencing product image, and consumer decisions to buy. Pricing is also related to revenue and also influences marketing demand and channels. The most important thing is that decisions in pricing must be consistent with the overall marketing strategy. Objectives are things that must be considered in deciding a pricing strategy. There are several objectives in determining the price, namely maximizing profits, maximizing sales, to survive, the rate of return on investment, prestige and prestige.

\subsection{Definition of Place}

According to Kotler and Armstrong (2016: 78) states place included company activities that make the product available to target consummers. And it can be interpreted that the place includes company activities to make products available to target consumers. Ratnasari (2011: 40) Place is a combination of location and decisions on distribution channels (related to where the strategic location is and how to match services to customers).

In service companies, place is a combination of decisions on distribution channels and location, in this case how to deliver services to customers and determine a very strategic location. Location or place is closely related to where the organization must be headquartered and operate to carry out its activities.

\subsection{Definition of Process}

According to Ratnasari (2011: 42) the process is a combination of all activities, generally consisting of procedures, work schedules, mechanisms and routine matters until services are produced and delivered to customers. The process can be divided into two ways, namely:

1. complexity, relating to the steps and stages in the process

2. diversity, associated with changes in steps or stages of the process.

According to Tjiptono (2014: 43) the identification of process management as a separate activity is a prerequisite for service improvement. The importance of this process 
element especially in service businesses is due to the unsustainable service inventory. In the service business, marketing management and operations management are closely related and difficult to clearly distinguish.

\subsection{Desire to Recommend}

Based on theoretical research, there are several basic concepts that can be used to determine the measuring tool "the desire to recommend", which relies on theories about customer satisfaction (customer satisfaction) or it can also be on the theory of customer loyalty (customer loyalty).

This "desire to recommend" measurement technique will be measured directly as in measuring customer satisfaction with questions that are directly reported (directly reported satisfaction) or according to the overall satisfaction assessment model (overall satisfaction), which is generally with only one question with 5 Likert scale answer choices. from "very dissatisfied" to "very satisfied". It can also refer to the model of "Customer Behavior Driving Factors" stated above, where "recommending services to others" is an indicator of loyalty and is sufficiently measured by one or several statement items that are direct and relevant.

\subsection{Hypothesis}

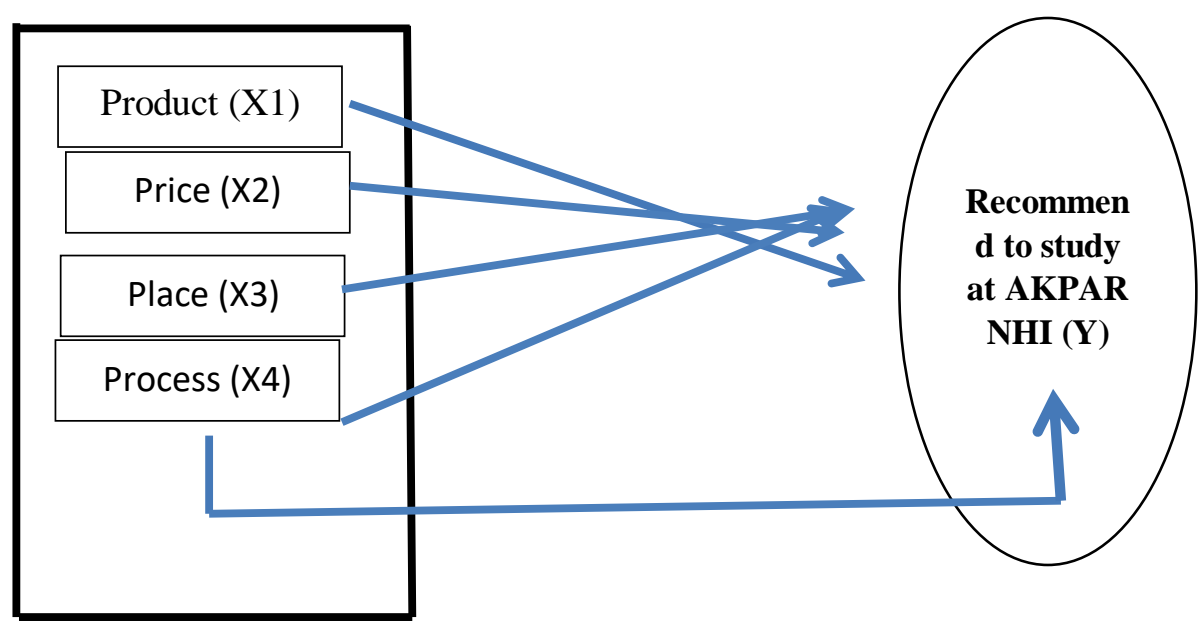

Figure 1. Research Paradigm

1. Partially the factors of product (product), price (price), place (place), and process (process) affect the desire of students to recommend courses at AKPAR NHI Bandung

2. Simultaneously the factors of product (product), price (price), place (place), and process (process) affect the desire of students to recommend courses at AKPAR NHI Bandung

\section{Research Methods}

\subsection{Research Approach}

The object of this study used 4 independent variables, namely Product (X1), Price (X2), Place (X3) and Process (X4), and 1 dependent variable, namely Desire to Recommend for College (Y).

The research approach used survey research with explanatory survey research type. According to Sugiyono (2014), the explanatory research method is a research method that intends to explain the position of the variables under study and the influence between one variable and another. Based on the type of research at the level of explanation, this type of 
research is associative research. Associative research is research that aims to determine the relationship between two or more variables. In the end, the results of this study explain the causal relationship between variables through hypothesis testing.

\subsection{Population and Sample}

According to Sugiyono (2018: 136) population is a generalization area consisting of objects/subjects that have certain quantities and characteristics set by researchers to be studied and then drawn conclusions. In this study, the population was students of the NHI Tourism Academy, even semester 2019-2020.

While the sampling method used in this study was simple random sampling. According to Sugiyono (2018: 140) simple random sampling is a technique of taking that provides equal opportunities for each element of the population to be selected as sample members which are carried out randomly regardless of the strata in the population.

To calculate the number of samples in this study is to use the Slovin formula, namely:

$$
\mathrm{nl}=\frac{\mathrm{N}}{1+\mathrm{n} e^{2}}
$$
follows:

In this study, the desired degree of sample error was $10 \%$. Thus the sample is as

$$
\begin{aligned}
& \mathrm{n}=\frac{848}{1+848(0,1)^{2}} \\
& \mathrm{n}=89.45 \text { people round to } 90 \text { people }
\end{aligned}
$$

\subsection{Data Analysis Method}

\section{a. Validity Test}

In this study, the validity test method will use the factor analysis method. The validity test will be calculated with the help of SPSS software by comparing the loading factor values in the Component Matrix table through factor analysis. The greater the loading factor value of the question item, the greater the correlation with the total construct score.

\section{b. Reliability Test}

The reliability in this study uses the Cronbach Alpha Coefficient formula which is calculated using the SPSS program with the following provisions:

- If the Cronbach Alpha coefficient $(\alpha)<0.6$ then the question item is declared unreliable.

- If the Cronbach Alpha coefficient $(\alpha)>0.6$ then the question item is declared reliable.

\section{c. Hypothesis Testing Design}

The research hypothesis regarding the effect of Product, Price, Place and Process on the desire of students to recommend courses at the NHI Bandung Tourism Academy was tested through hierarchical regression analysis which was carried out through the analysis of several regression models as well as hierarchically.

The regression model used in this test is as follows:

$$
Y=P y x 1 X 1+\operatorname{Pyx} 2 X 2+\operatorname{Pyx} 3 \mathbf{X 3}+\operatorname{Pyx} 4 X 4+\varepsilon
$$

Where:

$\mathrm{Y}=$ Desire to recommend

$\mathrm{Py}=$ Regression coefficient 
$\mathrm{X} 1=$ Product $($ Product)

$\mathrm{X} 2=$ Price $($ Price $)$

$\mathrm{X} 3=$ Place $($ Place $)$

$\mathrm{X} 4=$ Process (process)

$\varepsilon=$ Residual variables (disturbance terms)

\section{Result and Discussion}

\subsection{Overview of Respondents}

The general description of the students of the Bandung NHI Tourism Academy in this study is described by gender and generation, with a total of 90 respondents.

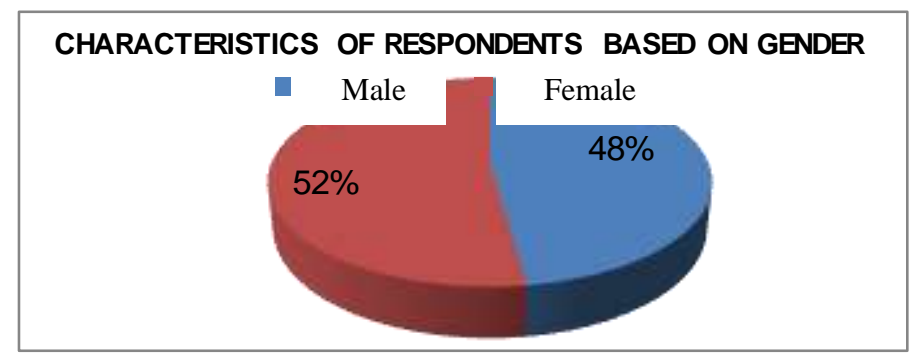

Figure 2. Characteristics of Respondents by Gender

From Figure 2 above, it can be seen that $48 \%$ of the respondents were male and $52 \%$ of the respondents were female.

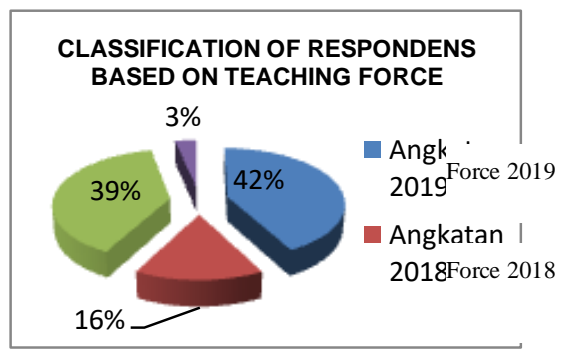

Figure 3. Classification of Respondents by Class Force

From Figure 3 above, it can be seen that the respondents in this study were $42 \%$ class 2019, $16 \%$ class 2018, 39\% class 2017 and 3\% class 2016.

\subsection{Results of Testing the Validity and Reliability of Research Instruments}

By using an alpha of $5 \%$ of the number of respondents 90 people, the correlation value of the product moment table is 0.205. The 21 statement items, the product moment correlation values for each statement item are greater than the product moment table correlation values, so it can be said that the statement items that have been stated are valid.

In testing reliability, the steps taken are the same as the validity testing steps. The results of the reliability test using SPSS are as follows: 
Table 3. Reliability

Statistics

\begin{tabular}{|r|r|}
\hline $\begin{array}{c}\text { Cronbach's } \\
\text { Alpha }\end{array}$ & N of Items \\
\hline .911 & 21 \\
\hline
\end{tabular}

4.3 Pinfluence partially the Product, Price, Place and Process on the desire of students to recommend courses at the NHI Bandung Tourism Academy

Table 4. Statistical Test Results Product Regression Coefficient (Product) and Desire to Recommend

\begin{tabular}{|c|c|c|c|c|c|}
\hline \multirow{2}{*}{ Model } & \multicolumn{2}{|c|}{$\begin{array}{c}\text { Unstandardized } \\
\text { Coefficients }\end{array}$} & $\begin{array}{l}\text { Standardized } \\
\text { Coefficients }\end{array}$ & \multirow[t]{2}{*}{$\mathrm{t}$} & \multirow{2}{*}{ Sig. } \\
\hline & B & Std. Error & Beta & & \\
\hline $1 \quad$ (Constant) & $-1,558$ &, 546 & & - & \\
\hline Product & 1,391 &, 140 &, 727 & $\begin{array}{l}2,802 \\
9,943\end{array}$ & 000 \\
\hline
\end{tabular}

a. Dependent Variable: Recommend

Table 5. Product Anova Statistical Test Results and Desire to Recommend

\begin{tabular}{|ll|r|r|r|r|c|}
\hline \multicolumn{1}{|c|}{ Model } & Sum of Squares & \multicolumn{1}{c|}{ df } & Mean Square & F & Sig. \\
\hline 1 & Regression & 39,417 & 1 & 39,417 & 98,872 & $.000 \mathrm{~b}$ \\
& Residual & 35,083 & 88 &, 399 & & \\
Total & 74,500 & 89 & & & \\
\hline
\end{tabular}

Table 6. Statistical Test Results of Product Summary Model (Product) and Desire to Recommend

\begin{tabular}{|l|c|r|c|c|}
\hline Model & $\mathrm{R}$ & $\begin{array}{c}\mathrm{R} \\
\text { Square }\end{array}$ & $\begin{array}{c}\text { Adjusted R } \\
\text { Square }\end{array}$ & $\begin{array}{c}\text { Std. Error of } \\
\text { the Estimate }\end{array}$ \\
\hline 1 & $.727 \mathrm{a}$ &, 529 &, 524 &, 63140 \\
\hline
\end{tabular}

a. Predictors: (Constant), Products

b. Dependent Variable: Recommend

Based on the results of testing or structural equations found, partially, the product factor (X1) with the desire to recommend (Y) is 0.727 . A positive coefficient value means that the Product factor partially has a positive effect on the desire to recommend to study at the NHI Bandung Tourism Academy.

The influence of the product (Product) with the desire to recommend the results obtained t count $>t$ table $(9.943>1.662)$ and significance $<0.05(0.000<0.05)$, so that Ho is rejected and it is concluded that partially, the product factor has an effect significant towards the desire of students to recommend courses at the NHI Bandung Tourism Academy at an error rate of $5 \%$.

The magnitude of the direct influence of the Product factor on the desire to recommend to study at the NHI Bandung Tourism Academy is obtained from the R2 (R Square) value of 
0.529 , meaning that the percentage of the contribution of the Product variable influence on recommending lectures is $52.9 \%$, while the rest is $47.1 \%$ is influenced by other factors. This shows that the Product variable has made a very large contribution, namely directly to the desire of students to recommend courses at the NHI Bandung Tourism Academy of 52.9\%.

Table 7. Statistical Test Results of Price Regression Coefficient (Price) and Desire to Recommend

\begin{tabular}{|l|l|r|r|r|r|r|}
\hline \multirow{2}{*}{ Model } & \multicolumn{2}{|c|}{$\begin{array}{c}\text { Unstandardized } \\
\text { Coefficients }\end{array}$} & $\begin{array}{c}\text { Standardized } \\
\text { Coefficients }\end{array}$ & \multirow{2}{*}{ t } & \multirow{2}{*}{ Sig. } \\
\cline { 3 - 7 } & B & Std. Error & Beta & & \\
\hline \multirow{2}{*}{1} & (Constant) & 1,196 &, 411 & & 2,906 &, 005 \\
\cline { 2 - 7 } & Price &, 734 &, 112 &, 572 & 6,534 &, 000 \\
\hline
\end{tabular}

a. Dependent Variable: Recommend

Table 8. Anova Statistical Test Results (Price) and the Desire to Recommend

\begin{tabular}{|l|l|r|r|r|r|r|}
\hline \multicolumn{2}{|c|}{ Model } & $\begin{array}{c}\text { Sum of } \\
\text { Squares }\end{array}$ & \multicolumn{1}{c|}{ df } & Mean Square & F & Sig. \\
\hline \multirow{2}{*}{1} & Regression & 24,338 & 1 & 24,338 & 42,698 & $.000 \mathrm{~b}$ \\
\cline { 2 - 7 } & Residual & 50,162 & 88 &, 570 & & \\
\cline { 2 - 7 } & Total & 74,500 & 89 & & & \\
\hline
\end{tabular}

a. Dependent Variable: Recommend

b. Predictors: (Constant), Price

Table 9. Statistical Test Results Model Summary Price (Price) and the Intention to Recommend

\begin{tabular}{|c|c|c|c|c|}
\hline Model & $\mathrm{R}$ & $\begin{array}{c}\mathrm{R} \\
\text { Square }\end{array}$ & $\begin{array}{c}\text { Adjusted } \mathrm{R} \\
\text { Square }\end{array}$ & $\begin{array}{c}\text { Std. Error of the } \\
\text { Estimate }\end{array}$ \\
\hline 1 & $.572 \mathrm{a}$ &, 327 &, 319 &, 75500 \\
\hline
\end{tabular}

a. Predictors: (Constant), Price

b. Dependent Variable: Recommend

Based on the results of testing or structural equations found, partially, the Price factor (X2) with the desire to recommend (Y) is 0.572 . A positive coefficient value means that the Price factor partially has a positive effect on the desire to recommend to study at the Faculty of Engineering, Widyatama University.

The effect of Price (Price) with the desire to recommend the results obtained $t$ arithmetic $>t$ table 6,534> 1.662) and significance $<0.05(0.000<0.05)$, so that Ho is rejected and it is concluded that partially, the Price factor has a significant effect against the desire of students to recommend courses at the NHI Bandung Tourism Academy at an error rate of 5\%.

The amount of direct influence of the price factor (Price) on the desire to recommend to study at the Faculty of Engineering, Widyatama University is obtained from the value of R2 (R Square) of 0,327 means that the percentage of the contribution of the influence of the price variable on recommending lectures is $32.7 \%$, while the remaining $67.3 \%$ is influenced by other factors. This shows that the Price variable has made a significant contribution, namely directly to the desire of students to recommend courses at the NHI Bandung Tourism Academy by $32.7 \%$. 
Table 10. Statistical Test Results of Place and Desire to Recommend Regression Coefficient

\begin{tabular}{|c|c|r|r|r|r|r|}
\hline \multirow{2}{*}{ Model } & \multicolumn{2}{|c|}{$\begin{array}{c}\text { Unstandardized } \\
\text { Coefficients }\end{array}$} & $\begin{array}{c}\text { Standardized } \\
\text { Coefficients }\end{array}$ & \multirow{2}{*}{ t } & \multirow{2}{*}{ Sig. } \\
\cline { 3 - 6 } & B & Std. Error & Beta & & \\
\hline \multirow{2}{*}{1} & (Constant) & 1,380 &, 377 & & 3,657 &, 000 \\
\cline { 2 - 7 } & The place &, 752 &, 113 &, 578 & 6,651 &, 000 \\
\hline
\end{tabular}

a. Dependent Variable: Recommend

Table 11. Anova Statistical Test Results Place (Place) and Desire to Recommend

\begin{tabular}{|c|l|r|r|r|r|l|}
\hline \multicolumn{2}{|c|}{ Model } & $\begin{array}{r}\text { Sum of } \\
\text { Squares }\end{array}$ & \multicolumn{1}{c|}{ df } & $\begin{array}{c}\text { Mean } \\
\text { Square }\end{array}$ & F & Sig. \\
\hline \multirow{2}{*}{1} & Regression & 24,921 & 1 & 24,921 & 44,234 & $.000 \mathrm{~b}$ \\
\cline { 2 - 7 } & Residual & 49,579 & 88 &, 563 & & \\
\cline { 2 - 7 } & Total & 74,500 & 89 & & & \\
\hline
\end{tabular}

a. Dependent Variable: Recommend

b. Predictors: (Constant), Place

Table 12. Statistical Test Results of the Summary Model Place (Place) and the Intention to Recommend

\begin{tabular}{|c|c|c|c|c|}
\hline Model & $\mathrm{R}$ & $\begin{array}{c}\mathrm{R} \\
\text { Square }\end{array}$ & $\begin{array}{c}\text { Adjusted } \\
\mathrm{R} \text { Square }\end{array}$ & $\begin{array}{c}\text { Std. Error of the } \\
\text { Estimate }\end{array}$ \\
\hline 1 & $.578 \mathrm{a}$ &, 335 &, 327 &, 75060 \\
\hline
\end{tabular}

a. Predictors: (Constant), Place

b. Dependent Variable: Recommend

Based on the results of the test or structural equation found, partially, the place factor (X3) with the desire to recommend (Y) is 0.578 . A positive coefficient value means that the Place factor partially has a positive effect on the desire to recommend to study at the NHI Bandung Tourism Academy.

The effect of Place (X3) with the desire to recommend the results obtained $t$ count $>t$ table $(6,651>1,662)$ and a significance of $<0.05(0,000<0.05)$, so that Ho is rejected and it is concluded that partially, the place factor ( Place) has a significant effect on the desire of students to recommend courses at the NHI Bandung Tourism Academy at an error rate of 5\%.

The magnitude of the direct influence of the Place factor on the desire to recommend to study at the Widyatama University Engineering Faculty is obtained from the R2 (R Square) value of 0,335 means that the percentage contribution of the influence of the Place variable on recommending lectures is $33.5 \%$, while the remaining $66.5 \%$ is influenced by other factors. This shows that the Place variable has made a significant contribution, namely directly to the desire of students to recommend courses at the NHI Bandung Tourism Academy by $33.5 \%$. 
Table 13. Statistical Test Results of Process Regression Coefficients and Desire to Recommend

\begin{tabular}{|l|l|r|r|r|r|r|}
\hline \multirow{2}{*}{ Model } & \multicolumn{2}{|c|}{$\begin{array}{c}\text { Unstandardized } \\
\text { Coefficients }\end{array}$} & $\begin{array}{c}\text { Standardized } \\
\text { Coefficients }\end{array}$ & \multirow{2}{*}{ t } & \multirow{2}{*}{ Sig. } \\
\cline { 3 - 7 } & \multicolumn{1}{|c|}{ B } & Std. Error & Beta & & \\
\hline \multirow{2}{*}{1} & (Constant) &,- 716 &, 601 & & $-1,191$ &, 237 \\
\cline { 2 - 7 } & Process & 1,206 &, 158 &, 631 & 7,627 &, 000 \\
\hline
\end{tabular}

a. Dependent Variable: Recommend

Table 14. Statistical Anova Test Results Process (Process) and Desire to Recommend

\begin{tabular}{|l|l|r|r|r|r|c|}
\hline \multicolumn{2}{|c|}{ Model } & $\begin{array}{r}\text { Sum of } \\
\text { Squares }\end{array}$ & df & $\begin{array}{c}\text { Mean } \\
\text { Square }\end{array}$ & F & Sig. \\
\hline \multirow{2}{*}{1} & Regression & 29,651 & 1 & 29,651 & 58,178 & $.000 \mathrm{~b}$ \\
\cline { 2 - 7 } & Residual & 44,849 & 88 &, 510 & & \\
\cline { 2 - 7 } & Total & 74,500 & 89 & & & \\
\hline
\end{tabular}

a. Dependent Variable: Recommend

b. Predictors: (Constant), Process

Table 15. Statistical Test Results of the Process Summary Model (Process) and the Desire to Recommend

\begin{tabular}{|c|r|r|r|r|}
\hline Model & R & $\begin{array}{c}\mathrm{R} \\
\text { Square }\end{array}$ & $\begin{array}{c}\text { Adjusted } \\
\text { R Square }\end{array}$ & $\begin{array}{c}\text { Std. Error of } \\
\text { the Estimate }\end{array}$ \\
\hline 1 & $.631 \mathrm{a}$ &, 398 &, 391 &, 71390 \\
\hline
\end{tabular}

a. Predictors: (Constant), Process

b. Dependent Variable: Recommend

Based on the test results or structural equations found, partially, the process factor (X7) with the desire to recommend $(\mathrm{Y})$ is 0.631 . A positive coefficient value means that the process factor partially has a positive effect on the desire to recommend to study at the NHI Bandung Tourism Academy

The effect of the process (X7) with the desire to recommend the result of $t$ count $>t$ table $(7,627>1,662)$ and a significance of $<0.05(0,000<0.05)$, so that Ho is rejected and it is concluded that partially, the process factor (process) has a significant effect on the desire of students to recommend courses at the NHI Bandung Tourism Academy at an error rate of 5\%.

The magnitude of the direct influence of process factors on the desire to recommend to study at the Faculty of Engineering, Widyatama University is obtained from the R2 (R Square) value of 0,398 means that the percentage contribution of the influence of process variables on recommending lectures is $39.8 \%$, while the remaining $60.2 \%$ is influenced by other factors. This shows that the process variable has contributed significantly significantly, namely directly to the desire of students to recommend courses at the NHI Bandung Tourism Academy at $39.8 \%$.

\subsection{Student Desire to Recommend Lecture at the NHI Bandung Tourism Academy}

To find the magnitude of the influence or contribution of variable $X$ to the rise and fall of variable $\mathrm{Y}$, it can be obtained from the coefficient of determination, namely to measure the extent of the coefficient levels between $\mathrm{X}$ variables, namely, product (X1), price (X2), place 
(X3), and process (X4), can explain the desire to recommend a lecture (Y). Based on data processing, it can be interpreted as follows:

Table 16. Statistical Test Results Model Summary

Marketing Mix and Desire to Recommend Lectures

\begin{tabular}{|c|r|r|r|r|}
\hline Model & $\mathrm{R}$ & $\begin{array}{c}\mathrm{R} \\
\text { Square }\end{array}$ & $\begin{array}{c}\text { Adjusted } \\
\text { R Square }\end{array}$ & $\begin{array}{c}\text { Std. Error of } \\
\text { the Estimate }\end{array}$ \\
\hline 1 & $.780 \mathrm{a}$ &, 608 &, 590 &, 58592 \\
\hline
\end{tabular}

a. Predictors: (Constant), Process, Place, Price, Product

b. Dependent Variable: Recommend

Table 17. Results of Anova Statistical Test for Marketing Mix and Desire to Recommend

\begin{tabular}{|c|c|c|c|c|c|c|}
\hline \multicolumn{2}{|c|}{ Model } & $\begin{array}{c}\text { Sum of } \\
\text { Squares }\end{array}$ & df & $\begin{array}{c}\text { Mean } \\
\text { Square }\end{array}$ & F & Sig. \\
\hline \multirow{4}{*}{1} & Regression & 45,320 & 4 & 11,330 & 33,003 & $.000 \mathrm{~b}$ \\
\cline { 2 - 7 } & Residual & 29,180 & 85 &, 343 & & \\
\cline { 2 - 7 } & Total & 74,500 & 89 & & & \\
\hline
\end{tabular}

a. Dependent Variable: Recommend

b. Predictors: (Constant), Process, Place, Price, Product

It appears that the coefficient of determination (R2) of 0.608 means that $60.8 \%$ of the variable of desire to recommend lectures can be explained by the independent variables in this case product, price, place, and process.

$\mathrm{R}$ square or the efficiency of determination shows how much variable $\mathrm{X}$ can describe the variable $\mathrm{Y}$. With an R-Square value of 0.608 , it means that the marketing mix variable can describe the variable of wanting to recommend college by $60.8 \%$. The remaining $39.2 \%$ is explained by variables not examined in this study.

With the value of influence above, it can be seen that the management of the NHI Bandung Tourism Academy has implemented their service marketing mix program with a success rate of $60.8 \%$. The rest, needs to be paid attention to other aspects in order to increase the desire to recommend courses at the NHI Bandung Tourism Academy instead of other universities.

\subsection{Hypothesis Results}

Table 18 shows a summary of the hypotheses made in Chapter II based on the analysis made by the authors.

Table 18. Summary of Hypothesis Results

\begin{tabular}{|c|c|c|c|}
\hline No. & Hypothesis & Statement & Information \\
\hline \multirow[t]{3}{*}{1.} & Hypothesis 1 & $\begin{array}{l}\text { The influence of product factor }(\mathrm{X} 1) \text {, on the desire to } \\
\text { recommend }(\mathrm{Y})\end{array}$ & \\
\hline & Ho: Pyx1 = 0 & $\begin{array}{l}\text { There is no positive influence between the Product } \\
\text { factor and the desire of students to recommend } \\
\text { courses at the NHI Bandung Tourism Academy }\end{array}$ & Rejected \\
\hline & На: Pyx $1 \neq 0$ & $\begin{array}{l}\text { There is a positive influence between the Product } \\
\text { factor and the desire of students to recommend } \\
\text { courses at the NHI Bandung Tourism Academy }\end{array}$ & $\begin{array}{c}\mathrm{Be} \\
\text { accepted }\end{array}$ \\
\hline
\end{tabular}




\begin{tabular}{|c|c|c|c|}
\hline No. & Hypothesis & Statement & Information \\
\hline \multirow[t]{3}{*}{2.} & Hypothesis 2 & $\begin{array}{l}\text { The effect of the Price factor }(\mathrm{X} 2) \text { on the desire to } \\
\text { recommend }(\mathrm{Y})\end{array}$ & \\
\hline & Ho: Рyx $2=0$ & $\begin{array}{l}\text { There is no positive influence between the Price } \\
\text { factor and the desire of students to recommend } \\
\text { courses at the NHI Bandung Tourism Academy }\end{array}$ & Rejected \\
\hline & Нa: Рyx $2 \neq 0$ & $\begin{array}{l}\text { There is a positive influence between the Price factor } \\
\text { and the desire of students to recommend courses at } \\
\text { the NHI Bandung Tourism Academy }\end{array}$ & $\begin{array}{c}\text { Be } \\
\text { accepted }\end{array}$ \\
\hline \multirow[t]{3}{*}{3.} & Hypothesis 3 & $\begin{array}{l}\text { The influence of the Place factor (X3) on the desire to } \\
\text { recommend (Y) }\end{array}$ & \\
\hline & Ho: Pyx3 = 0 & $\begin{array}{l}\text { There is no positive influence between the Place } \\
\text { factor and the desire of students to recommend } \\
\text { courses at the NHI Bandung Tourism Academy }\end{array}$ & Rejected \\
\hline & На: Pyx $\neq 0$ & $\begin{array}{l}\text { There is a positive influence between the Place factor } \\
\text { and the desire of students to recommend courses at } \\
\text { the NHI Bandung Tourism Academy }\end{array}$ & $\begin{array}{c}\mathrm{Be} \\
\text { accepted }\end{array}$ \\
\hline \multirow[t]{3}{*}{4.} & Hypothesis 4 & $\begin{array}{l}\text { Effect of process factors }(\mathrm{X} 7) \text { on the desire to } \\
\text { recommend }(\mathrm{Y})\end{array}$ & \\
\hline & Ho: Рyx3 = 0 & $\begin{array}{l}\text { There is no positive influence between process } \\
\text { factors and the desire of students to recommend } \\
\text { courses at the NHI Bandung Tourism Academy }\end{array}$ & Rejected \\
\hline & Ha: Pyx $\neq 0$ & $\begin{array}{l}\text { There is a positive influence between process factors } \\
\text { and the desire of students to recommend courses at } \\
\text { the NHI Bandung Tourism Academy }\end{array}$ & $\begin{array}{c}\mathrm{Be} \\
\text { accepted }\end{array}$ \\
\hline 5. & Hypothesis 5 & $\begin{array}{l}\text { Product factors (X1), Price (X2), Place (X3), and } \\
\text { Process }(\mathrm{X} 4) \text { have a positive effect on students' desire } \\
\text { to recommend courses at the NHI Bandung Tourism } \\
\text { Academy. }\end{array}$ & $\begin{array}{c}\mathrm{Be} \\
\text { accepted }\end{array}$ \\
\hline
\end{tabular}

\section{Conclusion}

Based on the results of the research and discussion that has been previously presented, several conclusions can be drawn as follows:

a. Partially the Product (X1), Price (X2), Place (X3) and Process (X4) variables significantly influence the desire of students to recommend college at the NHI Bandung Tourism Academy. The magnitude of the influence of each sub variable, namely: Product (Product) of $52.9 \%$, Price (Price) of 32.7\%, Place (Place) of 33.5\%, and Process (Process) of $39.8 \%$.

b. Simultaneously, the service marketing mix sub-variables together have a significant influence on the desire of students to recommend courses at the NHI Bandung Tourism Academy. The amount of the marketing mix variable can describe the variable willingness to recommend college by $60.8 \%$. The remaining $39.2 \%$ is explained by variables not examined in this study.

\section{Suggestions}

Based on the results of data analysis and the conclusions obtained in this study, the author can provide suggestions that might be used as material for consideration by institutions in determining Academy policies. The suggestions that the author wants to convey based on respondents' responses and research analysis are as follows: 
a. According to the results of the analysis, that among the independent sub-variables studied, the sub-process variable had the greatest influence on the desire of students to recommend courses at the NHI Bandung Tourism Academy. Therefore, the priority of improvement or improvement that must be carried out by Widyatama University is a process factor compared to other factors such as the level of ease in obtaining information related to studying on campus, the level of ease of handling how to pay tuition fees, the teaching and learning process on campus, the setting of lecture hours on campus, the level of student involvement in the teaching and learning process on campus, the participation of students' parents in extracurricular activities that students participate in.

b. Based on the results of the analysis of students' desires to recommend college or those who have recommended it has a high enough percentage, however, the management of the NHI Bandung Tourism Academy must pay attention to respondents who answer no desire or no response because this indicates dissatisfaction.

\section{References}

Azhar,A. (2018). Students' Trends in Islamic Communication Postgraduate in 2010-2016 State Islamic University of North Sumatera (UINSU). Budapest International Research and Critics Institute (BIRCI-Journal), P.206-214.

Buchari, Alma (2013), Manajemen Pemasaran Dan Pemasaran Jasa, Bandung: Alfabeta

Dianto, E., et al. (2020). BNI Marketing Strategy for Credit Cards in Dealing Global Competition in State Bank Indonesia (Persero) Tbk Banda Aceh Branch Office. Budapest International Research and Critics Institute-Journal (BIRCI-Journal). P. 11341146.

Effendy, A., \& Sunarsi, D. (2020). Persepsi Mahasiswa Terhadap Kemampuan Dalam Mendirikan UMKM Dan Efektivitas Promosi Melalui Online Di Kota Tangerang Selatan. Jurnal Ilmiah MEA (Manajemen, Ekonomi, \& Akuntansi), 4(3), 702-714. https://doi.org/10.31955/mea.vol4.iss3.pp702-714

Haque, MG., Munawaroh, Sunarsi, D., (2020). Analysis of SMEs Culinary Marketing Strategy During Covid 19 Pancemic: A Study at "Sate Bebek Cilegon" Resto in Cilegon, Banten. International Journal of Education, Information Technology, and Others. Vol.3. Issue 2

KEEGAN, Warren J., GREEN, Mark C.. (2015). Global Marketing (8th (Global Ed.)). Boston: Pearson Prentice Hall..

Kotler, Philip, Armstrong, Gary. (2016). Principles Of Marketing (16th). New Jersey: Pearson Prentice Hall..

Lupiyoadi, Rambat. (2013). Manajemen Pemasaran Jasa; Berbasis Kompetensi (3). Jakarta: Salemba Empat.

Purwanti, P., Sarwani, S., \& Sunarsi, D. (2020). Pengaruh Inovasi Produk Dan Brand Awareness Terhadap Keputusan Pembelian Konsumen Pada PT. Unilever Indonesia. Inovasi, 7(1), 24-31.

Putra, Bimantara A. (2015). Pengaruh Bauran Pemasaran Jasa Terhadap Keputusan Pembelian (Survei Pada Pelanggan Yang Menggunakan Jasa Pengiriman Di Kantor Pos Besar Kota Malang). Jurnal Administrasi Bisnis. Januari. Vol. 1, No. 1.

Ratnasari, Ririn Tri Dan Aksa, Mastuti H, (2011), Manajemen Pemasaran Jasa, Bogor : Ghalia Indonesia

Romdony, J., et al. (2019). Factors Affecting Customer Loyalty in Products. Budapest International Research and Critics Institute-Journal (BIRCI-Journal). P. 337-343.

Sugiyono, (2014) Metode Penelitian Bisnis, Bandung : Alfabeta 
Sugiyono, (2018) Metode Penelitian Bisnis, Bandung : Alfabeta

Sunarsi, D. (2019). Penerapan MSDM Strategis Dalam Upaya Meningkatkan Kemampuan Organisasi dalam menyongsong Revolusi 4.0. Jurnal Ilmiah MEA (Manajemen, Ekonomi, \& Akuntansi), 3(1), 221-233. https://doi.org/10.31955/mea.vol3.iss1.pp221233

Sunarsi, D., \& Baharuddin, A. (2019). The Effect of Service Quality and Price Accuracy on Consumer Confidence and Implications for Sales Increase. PINISI Discretion Review, 3(2), 101-110.

Supriyanto, Muhammad dan Taali, Muhammad (2018) Pengaruh Bauran Pemasaran (Marketing Mix) Terhadap Pengambilan Keputusan Menginap Di The Sun Hotel Madiun. Jurnal Epicheirisi, Vol. 2 No.1

Tjiptono, Fandy, (2014), Manajemen Jasa, Yogyakarta.: Andi Offset

Widada, Haryana Sapta (2017) Pengaruh Product, Price, Place, Promotion, Dan Physical Evidence Terhadap Keputusan Pembelian (Studi Pada Hotel Cakra Kusuma Yogyakarta) . Jurnal Upajiwa Dewantara, Vol.1, No. 1.

Wijoyo, H., Handoko, A. L., Santamoko, R., \& Sunarsi, D. (2020). Strategy Model For Character Education Through Digital Media For Courses And Training Participants. EProsiding Pascasarjana Universitas Negeri Gorontalo, 1-8.

Zeithaml, Valarie A., Bitner, Mary Jo. (2006). Services Marketing (4TH). New York: Mcgraw-Hill.) 